\title{
Good Practices and Results for the Implementation of a Framework of Sustainable Development in Higher Education ${ }^{+}$
}

\author{
Liviu Moldovan \\ Faculty of Engineering and Information Technology, "George Emil Palade" University of Medicine, Pharmacy, \\ Science, and Technology of Targu Mures, 1 Nicolae Iorga street, 540088 Targu Mures, Romania; \\ liviu.moldovan@umfst.ro; Tel.: +40-740-498-427 \\ + Presented at the 14th International Conference on Interdisciplinarity in Engineering-INTER-ENG 2020, \\ Târgu Mureș, Romania, 8-9 October 2020.
}

Published: 29 December 2020

\begin{abstract}
Sustainability assessment implies a complex evaluation due to its multidisciplinary aspects. The new eQvet-us framework for sustainability evaluation was developed based on the principle that training contributes to the development of human capital, enhances social cohesion and should also pursue financial sustainability and environmental responsibility. This paper presents the testing and implementation results of the framework for sustainable development in a higher education institution. It highlights good practices and results that can be used by other similar institutions, which carry out continuous training programs.
\end{abstract}

Keywords: quality framework; sustainability evaluation; vocational education and training; social responsibility

\section{Introduction}

The increasing recognition of environmental values in our society and the changing nature of work have necessitated a shift in the way that we think and act in learning and in life. The recent integration of generic skills into vocational education and training has paved the way for the inclusion of sustainability skills and can be used to provide direction in this process [1].

Education for sustainability [2,3] is now a widely accepted concept, which seeks to promote and develop sustainability skills and awareness [4,5] throughout a learner's educational pathway [6]. However, there is a lack of a comprehensive theoretical framework for understanding sustainable development and its complexities [7].

Sustainability assessment [8] implies a complex evaluation due to the multidisciplinary aspects [9] including environmental, economic and social, but also cultural factors [10], which has to be green [11]. Such an appraisal methodology supports decision making and institutional policy development. In this context, the assessment process requires an identification of the organizational aspects that contribute to a sustainable development and the ones that are not relevant for the purposes of the evaluation [12].

The new eQvet-us framework for sustainability evaluation [13] was developed based on the principle that training contributes to the development of human capital, enhances social cohesion and should also pursue financial sustainability and environmental responsibility. 
The objective of this paper is to test and implement the framework for sustainable development in a higher education institution and to highlight good practice results that can be used by other similar institutions that carry out continuous training programs.

\section{Method}

The research methodology consists of a series of steps thatneed to be taken byvocational education and training (VET) providers in order to: find out the state of the organization in the sense of eQvet-us; detect improvement possibilities; take measures for the improvement and monitor the results and the new state of the organization in the sense of continuous improvement [14].

EQvet-us quality framework establishes a series of indicators addressed at VET providers that already have quality management systems (QMS) incorporated in their organizations and wishes to continually improve the effectiveness of the quality management system, through the establishment of quality indicators in order to monitor and promote their sustainable development.

The EQvet-us framework is founded upon the 3 pillars of sustainable development: social, economic and environmental, embedded in the 7 social responsibility (SR) core subjects referenced in ISO26000, adapted to the training delivery context: organizational governance, human rights, labor practices, environment, fair operating practices, consumer issues, community involvement and development.

EQvet-us quality framework has been structured in 4 main phases, each of them corresponding to the 4 phases of the quality cycle, with respect to the training provision and delivery. For each correspondence with the core subjects of social responsibility eQvet-us framework establishes a specific indicator and a set of guiding questions, to support the self-evaluation process of VET providers with regard to the implementation of a sustainable model to continuously improve quality in VET. The list of indicators is presented in Table 1 according to each phase and respective activity.

In order to implement and use the eQvet-us framework in an organization, a practice set consisting of a self-diagnostic tool and implementation guide are elaborated [15]. 
Table 1. eQvet-us framework indicators matrix

\begin{tabular}{|c|c|c|c|c|c|c|c|c|}
\hline $\begin{array}{c}\text { eQvet-Us } \\
\text { Framework } \\
\text { Indicators Matrix }\end{array}$ & & $\begin{array}{l}\text { 1. Organizational } \\
\text { Governance }\end{array}$ & 2. Human Rights & 3. Labor Practices & 4. Environment & $\begin{array}{l}\text { 5. Fair Operating } \\
\text { Practices }\end{array}$ & $\begin{array}{l}\text { 6. Consumer } \\
\text { Issues }\end{array}$ & $\begin{array}{l}\text { 7. Community } \\
\text { Involvement and } \\
\text { Development }\end{array}$ \\
\hline \multirow[t]{2}{*}{$\begin{array}{c}\text { P. } \\
\text { Design of training } \\
\text { provision }\end{array}$} & $\begin{array}{c}\text { P.A. } \\
\text { Training } \\
\text { pathways } \\
\text { planning and } \\
\text { design }\end{array}$ & $\begin{array}{c}\text { P.A.1 } \\
\text { Decision making } \\
\text { processes and } \\
\text { structures }\end{array}$ & $\begin{array}{c}\text { P.A.2.1 } \\
\text { Accessibility of } \\
\text { trainingprogramsP.A.2.2 } \\
\text { Training programs addressed } \\
\text { to disadvantagedgroups }\end{array}$ & $\begin{array}{c}\text { P.A.3 } \\
\text { Health and Safety risk matrix }\end{array}$ & $\begin{array}{l}\text { P.A.4 } \\
\text { Environmental impact } \\
\text { plan }\end{array}$ & $\begin{array}{c}\text { P.A.5 } \\
\text { Fair operational } \\
\text { practices }\end{array}$ & $\begin{array}{l}\text { P.A.6 } \\
\text { Fair marketing \& } \\
\text { advertising } \\
\text { practices }\end{array}$ & $\begin{array}{c}\text { P.A.7 } \\
\text { Community engagement } \\
\text { actions }\end{array}$ \\
\hline & $\begin{array}{l}\text { P.B. } \\
\text { Curriculums } \\
\text { design }\end{array}$ & $\begin{array}{c}\text { P.B.1 } \\
\text { Existence of } \\
\text { multicultural } \\
\text { dimension }\end{array}$ & $\begin{array}{c}\text { P.B.2 } \\
\text { Training contents accessible } \\
\text { and understandable }\end{array}$ & $\begin{array}{c}\text { P.B.3 } \\
\text { Definition of practical } \\
\text { training materials }\end{array}$ & $\begin{array}{c}\text { P.B.4 } \\
\text { Environmentalcriteria } \\
\text { to select the training } \\
\text { materials }\end{array}$ & $\begin{array}{l}\text { P.B.5 } \\
\text { Commitment with } \\
\text { property rights }\end{array}$ & $\begin{array}{c}\text { P.B.6 } \\
\text { Curriculums } \\
\text { design for people } \\
\text { with special } \\
\text { educational needs }\end{array}$ & $\begin{array}{c}\text { P.B.7 } \\
\text { Training contents adapted } \\
\text { to the community and } \\
\text { company's needs. }\end{array}$ \\
\hline \multirow[t]{2}{*}{$\begin{array}{c}\text { I. } \\
\text { Training delivery }\end{array}$} & $\begin{array}{l}\text { I.A. } \\
\text { Implementation } \\
\text { of the training } \\
\text { path }\end{array}$ & $\begin{array}{l}\text { I.A.1 } \\
\text { Attribution of } \\
\text { training grants }\end{array}$ & $\begin{array}{c}\text { I.A.2 } \\
\text { Specific pedagogic approaches }\end{array}$ & $\begin{array}{l}\text { I.A. } 3 \\
\text { Existence of health and safety } \\
\text { conditions }\end{array}$ & $\begin{array}{l}\text { I.A.4.1 } \\
\text { Use of recycled } \\
\text { materials } \\
\text { I.A.4.2 } \\
\text { Waste recycling }\end{array}$ & $\begin{array}{l}\text { I.A. } 5 \\
\text { Ethical behavior } \\
\text { practices }\end{array}$ & $\begin{array}{l}\text { I.A.6 } \\
\text { Use of } \\
\text { stereotyped } \\
\text { materials }\end{array}$ & $\begin{array}{c}\text { I.A.7.1 } \\
\text { Partnership and } \\
\text { networking } \\
\text { I.A.7.2 } \\
\text { Work placements in } \\
\text { community organizations } \\
\end{array}$ \\
\hline & $\begin{array}{c}\text { I.B. } \\
\text { Learning } \\
\text { assessment }\end{array}$ & $\begin{array}{c}\text { I.B.1 } \\
\text { Assessment } \\
\text { mechanisms }\end{array}$ & $\begin{array}{l}\text { I.B.2.1 } \\
\text { Tools for the assessment of the } \\
\text { learning outcomes } \\
\text { I.B.2.2 } \\
\text { Learning recovery mechanisms }\end{array}$ & $\begin{array}{l}\text { I.B.3 } \\
\text { Verification criteria of the } \\
\text { working process }\end{array}$ & $\begin{array}{l}\text { I.B.4 } \\
\text { Environmental friend } \\
\text { evaluation tools }\end{array}$ & $\begin{array}{c}\text { I.B.5 } \\
\text { Transparency and } \\
\text { anticorruption } \\
\text { practices }\end{array}$ & $\begin{array}{l}\text { I.B.6 } \\
\text { Nondiscriminatory } \\
\text { assessment }\end{array}$ & $\begin{array}{c}\text { I.B.7 } \\
\text { Involvement and } \\
\text { participation of companies } \\
\text { and partners }\end{array}$ \\
\hline \multirow[t]{2}{*}{$\begin{array}{c}\text { E. } \\
\text { Training evaluation }\end{array}$} & $\begin{array}{l}\text { E.A. } \\
\text { Evaluation of } \\
\text { satisfaction }\end{array}$ & $\begin{array}{c}\text { E.A.1 } \\
\text { Assignment of } \\
\text { monitoring } \\
\text { mechanisms } \\
\end{array}$ & $\begin{array}{c}\text { E.A.2 } \\
\text { Degree of learners satisfaction }\end{array}$ & $\begin{array}{c}\text { E.A.3.1 } \\
\text { Degree of staff } \\
\text { satisfactionE.A.3.2 } \\
\text { Degree of trainers satisfaction }\end{array}$ & $\mathrm{N} / \mathrm{A}$ & $\mathrm{N} / \mathrm{A}$ & $\begin{array}{l}\text { E.A.6 } \\
\text { Degree of clients } \\
\text { satisfaction }\end{array}$ & $\begin{array}{c}\text { E.A.7 } \\
\text { Degree of satisfaction } \\
\text { among enterprises, } \\
\text { partners, stakeholders }\end{array}$ \\
\hline & $\begin{array}{c}\text { E.B. } \\
\text { Evaluation of } \\
\text { Training Impact }\end{array}$ & $\begin{array}{c}\text { E.B.1 } \\
\text { Evaluation } \\
\text { monitoring } \\
\text { mechanisms }\end{array}$ & $\begin{array}{c}\text { E.B.2.1 } \\
\text { Percentage of identified } \\
\text { positive resultsE.B.2.2 } \\
\text { Improvement of access to work }\end{array}$ & $\begin{array}{l}\text { E.B.3 } \\
\text { Improvement of the working } \\
\text { conditions }\end{array}$ & $\begin{array}{c}\text { E.B.4 } \\
\text { Improvement of the } \\
\text { environmental } \\
\text { consumption } \\
\end{array}$ & $\begin{array}{c}\text { E.B.5 } \\
\text { Long-term training } \\
\text { partnerships }\end{array}$ & $\begin{array}{c}\text { E.B.6 } \\
\text { Training impact } \\
\text { on trainees' job } \\
\text { performance }\end{array}$ & $\begin{array}{l}\text { E.B.7 } \\
\text { Employability within } \\
\text { thecommunity }\end{array}$ \\
\hline \multirow[t]{2}{*}{$\begin{array}{l}\mathrm{R} . \\
\text { Continuous } \\
\text { improvement }\end{array}$} & $\begin{array}{c}\text { R.A. } \\
\text { Self-evaluation }\end{array}$ & $\begin{array}{l}\text { R.A.1 } \\
\text { Self-evaluation } \\
\text { tools }\end{array}$ & $\begin{array}{l}\text { R.A. } 2 \\
\begin{array}{l}\text { Assurance of freedom of } \\
\text { expression }\end{array}\end{array}$ & $\begin{array}{c}\text { R.A.3.1 } \\
\text { Consultationwith all the staff } \\
\text { R.A.3.2 } \\
\text { Life balance mechanisms } \\
\end{array}$ & $\begin{array}{c}\text { R.A.4 } \\
\begin{array}{l}\text { Mechanisms to monitor } \\
\text { energy consumption } \\
\text { and waste }\end{array} \\
\end{array}$ & $\begin{array}{c}\text { R.A.5 } \\
\text { Feedbackto VET } \\
\text { provider staff }\end{array}$ & $\begin{array}{l}\text { R.A.6 } \\
\text { Handling } \\
\text { complaints }\end{array}$ & $\begin{array}{l}\text { R.A.7 } \\
\text { Initiatives with the } \\
\text { community }\end{array}$ \\
\hline & $\begin{array}{l}\text { R.B. } \\
\text { Training } \\
\text { pathways } \\
\text { reengineering }\end{array}$ & $\begin{array}{l}\text { R.B.1 } \\
\text { Modifications made } \\
\text { to the training } \\
\text { pathways }\end{array}$ & N/A & $\begin{array}{c}\text { R.B.3.1 } \\
\text { Modifications of working } \\
\text { processes relating to health } \\
\text { and safety conditions } \\
\text { R.B.3.2 } \\
\text { Logistic changes }\end{array}$ & $\begin{array}{l}\text { R.B.4 } \\
\text { Environmental } \\
\text { measures }\end{array}$ & $\begin{array}{l}\text { R.B.5 } \\
\text { Recognition and } \\
\text { reputation } \\
\text { strengthening }\end{array}$ & $\begin{array}{c}\text { R.B.6 } \\
\text { Pricing strategy } \\
\text { re-evaluation }\end{array}$ & $\begin{array}{c}\text { R.B.7 } \\
\text { Good practices and transfer } \\
\text { of experiences }\end{array}$ \\
\hline
\end{tabular}




\section{Results}

The VET provider Continuous Education Centre (CEC) from “George Emil Palade" University of Medicine, Pharmacy, Science, and Technology of Targu Mures (UMFST) conducted a pilot test for the implementation of a framework for sustainable development and the self-assessment tool over one week. The test involved a group of four staff members with different jobs: a training coordinator in charge of relations with companies, a trainer, a quality assurance specialist and administrative assistant. At the end of the self-assessment and diagnosis, the information was used in a common meeting for an internal improvement action plan proposal.

It was appreciated that the sustainability enforcement already exists in many different forms and diverse levels at UMFST in particular and throughout Romanian VET providers in general. The overall appreciation of the pilot implementation at UMFST is positive and revealed some results.

As regards environmental sustainability the outlined practices in each indicator are:

P.A.4 Environmental impact plan-the environmental connection of UMFST as a VET provider was not clear at first sight, but like in the case of every other institution or enterprise, it was concluded that the organization has to make decisions with an environmental impact on a daily basis. UMFST starts from the service delivery and consumption involving many factors, which are mentioned in the environmental pillar, such as the waste problem, resource productivity and consumption. Additionally, UMFST will encourage suppliers to improve the environment imposing relevant environmental requirements for their supplied products in order to reduce environmental impact.

P.B.4 Environmental criteria to select the training materials- the vision of the paperless class and office are still topical. "Going Paperless" can save money and space, produce electronic documentation and information easier to share, which minimize the environmental damage. On the other hand, it was showed that the introduction of the personal computer to offices increased paper usage instead of minimizing it, as it facilitated paper prints even if this was not necessary. Regarding the curricular content of the training materials, it is essential to highlight the importance of education for all trainees to achieve sustainable development. The competence-based model is the means of achieving educational and societal transformation towards sustainability, framed by a shared vision about quality education and a society that lives in harmony with the world's natural capacity. Environmental education-in whatever form-actually supports and promotes more sustainable development in practice; its development is accompanied by the implementation of a problem-based learning approach, environmental impact assessment, environmental protection rules and integration of knowledge management.

I.A.4.1 Use of recycled materials - the main issue was to use digital documents in order to reduce paper consumption. Higher emphasis is placed on recycling printed paper, but also on the delivery of materials electronically rather than on paper. Another issue is related to the possibility that suppliers recover used products for recycling, such as toner cassettes for printers, copying machines and faxes. Another measure is the use of recycled plastic/paper garbage bags, reuse of printing and copying materials packaging materials, boxes, etc.

I.A.4.2 Waste recycling - the first step is to promote and ensure recycling, waste separation and circular economy. This approach is followed byissues related to the reuse of paper and separate waste collection.

I.B.4 Environmental friendliness evaluation tools-the main issue related to this topic is the use of assessment methods, which can be applied electronically rather than on paper. This approach will be extended via the use of software evaluations during classes and exams using computers, laptops, tablets and iPods, by extending the existing software such as: the student response system (SRS), peer learning evaluation (PeLe), One2act and also the learning management systems-Moodle. A supporting factor is that most of the students have mobile phones with touch sensitive screens that facilitate mobile learning in large course-rooms with Wi-Fi networks.

E.B.4 Improvement of the environmental consumption-regarding theuse of raw materials, the main issue is the reduction of paper consumption due to electronic learning supports. The delivery 
of materials in electronic rather than paper-based format is encouraged, in addition to printed paper recycling. The objective of water managementaims to minimize consumption. Optimization is performed by developing awareness of staff members and participation in training courses. Additionally, sustainable consumption was promoted by providing course participants and employees with the possibility to purchase fair-trade products and locally produced fruits during course breaks. This reflects the idea of integrating environmental concerns into the decision making process of businesses, labeled as "Green Business".

Another issue was that the production of electronic devices, such as tablets, computers, etc., consumes a lot of natural resources (water, raw materials such as Coltan, etc.) and the use of a "green computer" is a key requirement in this context.

R.A.4 Mechanisms to monitor energy consumption and waste- the starting point was climate change and energy and it was appreciated that energy efficiency is probably the most important aspect to which UMFST can contribute as a VET provider. This includes logistics, an evaluation of the course locations in terms of heating, water consumption and current supply, and "energy education": this implies energy saving methods and stafftraining with regard to these measures (e.g., turn off the lights when leaving the office, avoid stand-by, etc.) using energy-saving controls. Additionally, UMFST aims to decrease electricity consumption by using energy-efficient equipment: fluorescent lamps, lighting control in rooms with low traffic by installment of detectors and signs for light turn-off. When buying new technological devices for the office (e.g., computers and mobile phones), an important factor is the energy consumption of the device and its energy-saving potential. While it is always possible to act efficiently from the perspective of energy consumption, it may be more complicated to promote clean energy. Then it was recommended that UMFST should search for providers who offer clean energy supply.

R.B.4 Environmental measures-in regards to water pollution, the chemicals are envisaged by reduction in the use of environmentally hazardous products: the chemicals risk phases are written down in plain text on a chemical list; good laboratory safety and chemical management is ensured in order to reduce the risk of injury on the environment and human health and non-chemical cleaning methods are used where it is possible. In regards to soil management and pollution, the use of products that respect the environment and have local origin is promoted and encouraged. By imposing relevant environmental requirements to suppliers to reduce their environmental impact and encourage suppliers to improve the environment, UMFST is committed to purchasing products, which cause as little environmental damage as possible, the ecolabels. The European ecolabel (ecolabel printing and copying paper and envelopes) is the guarantee of trust, which informs suppliers with regard to UMFST environmental requirements: a written environmental policy and a diploma or certification about the products. In the advertising and marketing process, all externally produced printed materials, etc., are ecolabeled, which implies an environmentally friendly printing process. Rechargeable small batteries are used. In regards to air pollution and greenhouse gas, efforts are concentrated on transport-related issues. Contacts, human encounters and communication are key elements of UMFST business. Meetings can be implemented in different ways. The active selection of environmentally friendly means of transportation can reduce the environmental impact. UMFST will promote holistic travel and transport, including avoiding unnecessary traveling by making use of various remote meeting systems: internet conference, Skype meeting, video laboratory meetings with codecs, etc.; leverage of own technology expertise to develop new ways of "remote working"; promoting and development of car-sharing practices; increasing information regarding public transports and greater use of trains and buses instead of cars and planes.

As regards the social sustainability, the relation between the UMFST added value and its social impact were analyzed. Efforts are concentrated towards minimizing negative social impact such as work accidents, human rights abuses, exploitation, mobbing of employees, etc., and maximizing positive ones, in relation to the added value. 
Actions within the sphere of social responsibility include providing continuing education and training for staff in the framework of annual programs organized by UMFST, compatibility of career-work—and private life (e.g., by offering study facilities for member families), job safety and health assurance by a specialized service and equal opportunities for all human beings employed in UMFST.

UMFST has ensured that all employees have a health insurance according to the legal regulations of Romania. They work in an environment that promotes good health rather than causing health problems (through stress, mobbing, exhaustion, excessive demand, etc.). UMFST guarantee that basic human needs are met; this includes sufficient space and breaks, pleasant room temperatures, comfortable chairs, fresh air, etc. UMFST trainers and teachers are instructed annually in order to have the ability to give first aid and react adequately in situations of danger like: in the case of fire, earthquake and distress. UMFST is aware of its role as a health educator in the sense that it helps staff to improve their knowledge about health and hygiene and equips them with the skill to make provisions for their own health.

As regards social inclusion, the challenge resides in motivating "education resistant" groups to participate in educational activities and in including people who cannot afford to participate in VET courses due to their occupational duties and to economic constraints. For this purpose, we organized the Open Distance Learning Department, which offers distance learning for trainees who cannot attend daily courses.

As regards demography, UMFST is concerned with ensuring diversity by the employment of young people due to the fact that there are many teachers who are over 50 years old.

The economic sustainability is the central focus of socioeconomic sustainable development and sustainable consumption and production. We performed analyses regarding the number of trainers/teachers in relation to the number of trainees/students, but the perspective to expand is limited due to the demographic decrease.

The Counseling and Career Orientation Centre performs regular studies about the number of graduates who are able to enter the labor market after having completed a degree/training course.

The economic aspect is analyzed in terms of UMFST profitability regarding investments in research, development and innovation.

Sustainable consumption and production will be promoted by providing course participants and employees the possibility to purchase fair-trade products during course breaks in the university restaurant. A report about UMFST sustainability is posted on the institutional website [16].

\section{Conclusions}

The eQvet-us framework is different from others in terms of its objective, which consists of determiningenvironmental impactimproving the environmental, economic, social and quality of the training system.

The assessment tool helps training providers in order to: (a) check the level of performance for each area within the framework; (b) identify improvement possibilities for all categories and (c) make decisions and set priorities in relation to the three pillars, activities and business projects.

With this support, an innovative aspect of the framework is that it promotes the development of a strategy based on performance indicators that integrates sustainable development.

We consider that sustainable development strategy has a central role in the competitive strategy of the organization and we believe that it determines the other competitive strategies of a VET provider: marketing, training delivery, partnerships, etc. Such strategies describe how the VET provider plans to gain advantage over competitors, for example with the support of technology by using new educational technologies such as distance training, blended learning, learning management systems and video systems for the delivery of training with paperless support; strategies using the alternance model for training by working part-time with an employer; etc. 
In regards to the methodological approach of the new framework for sustainable development, the multitude of indicators employed requires an assessment group of committed experts to accomplish the assessment.

The quality of the assessment depends on the availability of data at the assessed institution. In optimal conditions, the results of the assessment have to be objective and precision may be an issue that facilitates the progress of evaluations.

The results of self-evaluation are adequate to be used for establishing a sustainability baseline, to identify possibilities for improvement, and to prioritize the implementation.

Furthermore, the results can be used to develop sustainability policies and action plans, establish performance guidelines and improve internal sustainability performance of institutions in various fields of activity $[17,18]$. This will have direct relevance to improved economic and social performance, institutional effectiveness and an enhanced image of the organization [19,20].

Graduates of such institutions that implement the framework for sustainable development will naturally be sustainability driven.

Funding: This research was funded by the Erasmus+ European Programme, project number 2014-1-RO01-KA202-002758, project title "European Quality Assurance in VET towards new Eco Skills and Environmentally Sustainable Economy".

Conflicts of Interest: The author declares no conflict of interest.

\section{References}

1. Goldney, D.; Murphy, T.; Fien, J.; Kent, J. Finding the Common Ground: Is There a Place for Sustainability Education in VET? A National Vocational Education and Training Research and Evaluation Program Report. Available online: https://eric.ed.gov/?id=ED499704 (accessed on 20 March 2020).

2. Moldovan, L. Design and development of innovative tools and models for e-learning in central and western Romania. In Proceedings of the 6th International Seminar Quality Management in Higher Education-QMHE2010, Tulcea, Romania, 8-9 July 2010; Volume II, pp. 543-546.

3. Moldovan, L. Innovative tools and models for vocational education and training. In Review of Management and Economic Engineering-First Management Conference: Twenty Years after-How Management Theory Works; Todesco Publishing House: Cluj-Napoca, Romania, 2010; Volume 9, pp. 282-290.

4. Moldovan, L. Innovative Models for Vocational Education and Training in Romania. Procedia Soc. Behav. Sci. 2012, 46, 5425-5429. [CrossRef]

5. Moldovan, L. Innovative Method of Peer Assisted Learning by Technology and Assessment of Practical Skills. Procedia Technol. 2014, 12, 667-674. [CrossRef]

6. Moldovan, L. Design of a New Learning Environment for Training in Quality Assurance. Procedia Technol. 2014, 12, 483-488. [CrossRef]

7. Jabareen, Y. A New Conceptual Framework for Sustainable Development. Environ. Dev. Sustain. 2006, 10, 179-192. [CrossRef]

8. Moldovan, L. Sustainability Assessment Framework for VET Organizations. Sustainability 2015, 7, 7156-7174. [CrossRef]

9. Moldovan, L. New Evaluation Model by Means of Mobile Technology. Procedia Technol. 2015, 19, $1094-1101$. [CrossRef]

10. Moldovan, L. Training outcome evaluation model. Procedia Technol. 2016, 22, 1184-1190. [CrossRef]

11. Moldovan, L.; Moldovan, A.-M. Green Methodology for Learning Assessment. Procedia Technol. 2016, 22, 1176-1183. [CrossRef]

12. Sala, S.; Ciuffo, B.; Nijkamp, P. A systemic framework for sustainability assessment. Ecol. Econ. 2015, 119, 314-325. [CrossRef]

13. Moldovan, L. Framework Development for European Quality Assurance in VET Towards Environmentally Sustainable Economy. Procedia Eng. 2017, 181, 1064-1071. [CrossRef]

14. Moldovan, L. The Environmental Pillar Assessment in Vocational Education. Environ. Eng. Manag. J. 2017, 16, 739-750. [CrossRef] 
15. Moldovan, L. Practical Implementation of a Framework for European Quality Assurance in VET towards Environmentally Sustainable Economy. Procedia Eng. 2017, 181, 1072-1079. [CrossRef]

16. Mikolajczyk, T.; Moldovan, L.; Chalupczak, A.; Moldovan, F. Computer Aided Learning Process. Procedia Eng. 2017, 181, 1028-1035. [CrossRef]

17. Sustainable Development Report of "George Emil Palade" University of Medicine, Pharmacy, Science and Technology of Târgu Mureș (UMFST). Available online: https://green.umfst.ro/?pdf=En_UMFST_ sustainability_report (accessed on 8 July 2010).

18. Moldovan, F. New Approaches and Trends in Health Care. Procedia Manuf. 2018, 22, 947-951. [CrossRef]

19. Moldovan, L. QFD Employment for a New Product Design in a Mineral Water Company. Procedia Technol. 2014, 12, 462-468. [CrossRef]

20. Ciobanu, I.; Stanculescu, D.I.; Iliescu, A.; Popescu, A.M.; Seiciu, P.L.; Mikolajczyk, T.; Moldovan, F.; Berteanu, M. The usability pilot study of a mechatronic system for gait rehabilitation. Procedia Manuf. 2018, 22, 864-871. [CrossRef]

Publisher's Note: MDPI stays neutral with regard to jurisdictional claims in published maps and institutional affiliations.

(C) 2020 by the author. Licensee MDPI, Basel, Switzerland. This article is an open access article distributed under the terms and conditions of the Creative Commons Attribution (CC BY) license (http://creativecommons.org/licenses/by/4.0/). 